\title{
Information Systems in Agricultural Enterprises: An Empirical Study in Slovak Republic
}

\author{
Anna Látečková1, Vladimír Bolek ${ }^{2}$, L’uboslav Szabo $^{3}$ \\ ${ }^{1}$ Department of Accounting, Faculty of Economics and Management, Slovak University of Agriculture \\ in Nitra, Slovak Republic \\ ${ }^{2}$ Department of Information Management, Faculty of Business Management, University of Economics \\ in Bratislava, Slovak Republic \\ ${ }^{3}$ Department of Management, Faculty of Business Management, University of Economics in Bratislava, \\ Slovak Republic
}

\begin{abstract}
The development of information and communication technologies (ICT) is currently conditioned by the development of industry, society and many other factors. The ever increasing trend of ICT development is directly connected with the agricultural enterprises. ICT play important roles in the development of these enterprises and automation of their processes. Revitalisation of financing and budgets, dynamically evolving strong competitive environment and growing regulation lead to ever growing need for swift reactions and making precise decisions in all institutions and organisations, including manufacturing and agricultural organisations. Access to the right information in the right time is crucial for every subject. There are several fundamental areas for modern agricultural enterprises. All processes carried out in agricultural enterprises need to be planned and managed; automation of the processes via suitable information systems brings significant competitive advantages and strengthened market positions. Enterprise resource planning systems are convenient in this respect. The systems represent efficient instruments for planning and management of all crucial internal processes, particularly at the tactical and operational levels of management. The paper provides a picture of the current state of business information systems' application in agricultural enterprises in Slovak republic and analyses the influence of selected factors (benefits and functions of the information system) on the satisfaction of managers with the implemented information system.
\end{abstract}

\section{Keywords}

Information systems, information and communication technologies, management, benefits, agricultural enterprises.

Látečková, A., Bolek, V. and Szabo, L'. (2018) “Information Systems in Agricultural Enterprises: An Empirical Study in Slovak Republic", AGRIS on-line Papers in Economics and Informatics, Vol. 10, No. 2, pp. 49-60. ISSN 1804-1930. DOI 10.7160/aol.2018.100105.

\section{Introduction}

The reproduction processes are characteristic with overlapping information systems and information technologies Implementation of information systems providing competitive advantages at domestic and foreign markets through efficient provision of information becomes a crucial factor of successful development and sustainable market position. Agricultural enterprises are also affected by the trend of computerisation. ICTs have a demonstrable positive effect on income growth in developing and developed countries (Röller and Waverman, 2001; Waverman et al., 2005). In rural areas, ICTs can raise incomes by increasing agricultural productivity (Lio and Liu, 2006) and introducing income channels other than traditional farm jobs. Current limited evidence from individual farmers and fishers in India supports the conclusion that ICTs improve incomes and the quality of life among the rural poor (Jensen, 2007; Goyal, 2010). The idea that wider access to and use of ICTs throughout a country will reduce inequalities in income and quality of life between rural and urban residents is compelling. Despite the scarcity of evidence to support this notion (Forestier et al., 2002), it underlies widespread policy initiatives to ensure equitable access to ICTs in all areas. Maumbe and Okello (2010) point to ICTs as a powerful tool in the area of agriculture 
and rural development also in developing countries.

After 1992, there was a boom of information systems in the sector of agriculture, when the unified business system and the medium management were gradually being supplemented by a large growth of new installations provided by various software companies, both domestic and foreign ones. During the transition period, the foreign software products (provided by e.g. KW or Siemens) did not position themselves between centrally planned economy and market economy in the specific conditions of agriculture. Software products of domestic companies such as Softteam, Kubiko Codex, Aurus or Intes have currently marked the trend of the qualitative improvement.

Globalisation processes significantly affect the ways of practical management. The needs for pertinent information and the detailed knowledge of internal and external environment of an enterprise come to the forefront. There have been opened new possibilities for positioning at foreign markets, after Slovakia entered to the European Union. This has conditioned the increased requirements for information security. The new conditions within the European Union must also be reflected by information systems of agricultural subjects. Information policy stipulates the activities which are about to be implemented in the sphere of information technologies in organizations and what the reasons behind the activities are.

In the short-term to the medium-term period, agriculture in the Slovak Republic must react to several challenges stemming from the finishing transformation of economy, changes in the world economy and access to the common market of the European Union in 2004. Agricultural sector (Kuncova et al., 2016) belongs to the primary sectors depending mainly on the natural resources. Although it is usually less important than the secondary and tertiary sectors (especially in the developed countries) it has an indispensable role in economy.

In the ever harsher competition, agricultural managers are aware of the value of information; however, corporate information systems are not at the sufficient level. In order to ensure permanent competitiveness, it is necessary to modify the existing information systems and link them with the external environments. The issue of computerisation is also tackled by the Ministry of Agriculture and Rural Development of the Slovak Republic. In order to provide systemic and complex approach to the duties connected with building efficient information systems, the ministry has elaborated a set of documents defining all necessary tasks which will have to be implemented in the sector of agriculture in accordance to the global development of information society. The implementation of the Conception of Agricultural Policy and Computerisation Programme is considered strategic from the viewpoint of the ministry management and its sections and also rom the perspective of creating the necessary information and communication links. Both documents represent conceptions of the sector focused on systemic enforcement of information and communication technologies in favour of building information systems and other necessary instruments. The structure and the content of the projects have been derived from the goals and priorities of the sector as well as the tasks related to the pre-accession strategy. The goal of the Computerisation Programme is to gradually complete the information system of the sector as a unified system of mutually connected and cooperating information systems, able to provide information and necessary services in favour of the sector management, other sectors and also public.

Management is a complex process and proper decisions need to be based on the available objective and trustworthy data. At the same time, it is necessary to differentiate operational, tactical and strategic management. The best solution is to possess data to address all needs of managers and to make them available on a real time basis. It is a complicated task at first sight. Moreover, when the ever growing volume of data is taken into consideration, the demand is quite problematic. However, implementation of suitable information system and technologies makes it feasible to store large volumes of data, process them in a short time and provide managers with outcomes in required formats (calculations, graphical depictions, multidimensional analyses).

A business information system providing relevant information has to take into consideration the character of business activities in an enterprise, information flows, implemented software and hardware, and it shall enable introduction of modern tools to support financial management.

\section{Theoretical background}

The current management and decision-making of top management are affected by turbulent and sometimes very unpredictable environment, which is linked to the large scale of globalisation 
and critical factors at financial and bank markets. Except of the previously mentioned impacts of globalisation on export economies (which is also the case of Slovakia), we also face other problems: swift changes, enormous increase in structured and particularly non-structured data, operationality etc. Top managers willing to maintain the competitiveness of their organisation need to cope with the reality in qualitatively new ways; i.e. to use the most recent managerial technologies in combination with the IT instruments. Primarily, they need to adopt the use of the Enterprise Resource Planning (ERP) and Business Intelligence (BI) systems as the inevitable instruments of management. This problems are closely related to the sector of agriculture, too.

The ERP systems automate and integrate crucial business processes such as receiving orders, planning processes, registering supplies and financial data. The ERP systems contribute to improved business efficiency. Among the most important advantages of such systems belong (Novotný et al., 2005, Williams and Williams, 2007, Basl and Blažíček, 2008; Gartner, 2016):

- assistance in defining business processes and assuring they are preserved in the whole supply chain,

- protection of important business data through appropriate role definition and access policy,

- work-time planning based on existing orders as well as predictions,

- providing customers with tools at high level of services,

- transformation of business data to a form convenient for flexible decision-making

The modern ERP solutions cover a decisive part of business processes; therefore, it can be stated that one of the most important tasks in defining the information strategy of a corporation is paying enough attention to defining the most suitable ERP system.

The most relevant reasons for introducing the ERP systems are as follows (Novotný, et al., 2005, Williams and Williams, 2007, Basl and Blažíček, 2008; Gartner, 2016):

1. providing a corporation with a wide scale of functions covering the wide scope of basic activities,

2. support of internal and external processes and the possibility to optimise the processes,

3. possibility to decrease the number of operational systems,
4. ERP is a corner stone of a corporate IT architecture,

5. globalisation requires introduction of the homogenous ERP system,

6. efficient corporate strategy is based on aggressive and effective use of information technologies,

7. competitive advantage or becoming equal to compete.

Requirements related to system functions, references or criteria related to solution suppliers are important and even unambiguous.

Business intelligence helps to clarify achieved results, optimise operational models and support flexible and swift decision-making process. The following definition of business intelligence is widely accepted: business intelligence (BI) is a set of procedures, processes and technologies aimed at efficient and purposeful support of decisionmaking processes in corporations. It represents a complex of applications supporting analytical and planning activities of enterprises and organisations based on specific, so-called OLAP technologies and their modifications. Recently, the term Business Intelligence has been used to replace the term MIS (Management Information System). The areas covered by BI are not strictly defined; e.g. it is used to support business strategy and marketing. Competitive Intelligence (analysis of competition and competitive environment), expert systems or DSS (Decision support system) are examples of areas often incorporated to BI; however, they can be also addressed as separate units (Basl and Blažíček, 2008).

There is still a low level of the Business intelligence introduction among businesses, which could be explained by low level of information about the software. According to the research by Hamranová (2013), there are only $22 \%$ of enterprises in Slovak republic with the implemented Business intelligence applications. The Business intelligence applications are important in agricultural enterprises, too (Tyrychtr et al. 2015). The current Business intelligence applications are focused particularly on flexibility, interactivity and the ability to acquire the most exact information possible in the shortest possible time period and in the simplest possible way so that further new facts could be derived from the information and thus create an added value to decision-making. The most exact and complex data possible, able to reveal background effects leading to undesired deviations, are necessary 
for daily operative and tactical decision-making as well as singular crucial strategic resolutions. The Business intelligence applications help managers to find answers to many questions. The Business intelligence applications are useful for making activities in corporations more efficient while enhancing independent thinking.

The access to information is not available without the use of new ICT - all technological, programmerelated and organisational means aimed at processing information. Each enterprise owns a set of information located in files, databases and documents. The information is vital for decision-making at all management levels. To make the decisions as flawless as possible, managers need the access to correct, precise and consolidated information in proper time.

Stuchly and Krutakova (2015) claim that currently, enterprises must fight with uncertainty if they want to survive in the strong competition and try to alleviate it. Each enterprise is doing it a little different way, and choosing a different strategy. It is important to constantly developing and adapting of management system to external conditions and strategies which the enterprise decided to apply.

The managers, who want to maintain the competitiveness of their organisation, need to cope with the reality in qualitatively new ways; i.e. using the most recent managerial technologies in combination with the IT instruments (Scheps, 2008).

An important factor for a successful development and maintenance of competitiveness of business subjects is implementation of economic information systems, providing competitive advantages at domestic and foreign markets through effective use of information. An economic information system (Kokles and Romanová, 2007) represents an essential part of a corporate information system. It is primarily focused on gathering, processing and providing information, expressing the economic reality of a corporation.

It is necessary that a software application addressing accounting provides databases meeting operational, tactical and also strategic needs - this is the fundament of a properly designed business information system.

According to Tóth (2012), an accounting system has to be understood as an integral part of a business information system. Automated processing of accounting information could be considered to be a routine. A software solution is important in this respect. Enterprises could choose from desktop versions, but the trend of evolution in this area leads to cloud versions of software. Cloud computing is considered to be a concept of providing information technologies through the Internet via rental. Electronic information is stored and saved on external servers in large data centres (Armbrust et al., 2010). The current trend of ICT development, the demand on early and relevant information makes the enterprises use cloud solutions and to integrate the module accounting to the existing IS, or to implement complex ERP systems. In our opinion, it is proper to choose the variant, as it makes the processes more efficient, leading to increased competitiveness of enterprises, though cloud computing brings also certain risks. The most important risk is related to the information security - safety and access to sensitive data and trustworthiness of a provider. The service availability is not that risky nowadays since technologies work on the principle of offline/ online Internet connection to the service.

It could be stated that information and communication technologies are essential for increasing competitiveness of agricultural enterprises and business dealing with agritourism (Havlíček et al., 2009). They pose a competitive advantage and offer possibility to make a difference on the market, to strengthen a market position and attract new clients. Maumbe and Okello (2010) also claim that information and communication technologies are powerful instruments for strengthening competitiveness in agriculture and rural development even in the Third World.

\section{Materials and methods}

The main research objective is to identify benefits and functions of business information systems representing a crucial support for management and decision-making in agricultural enterprises, assisted by accounting data.

Business information systems in the selected agricultural enterprises are the objects of interest. With respect to the objectives, we put emphasis on business information systems and economic software.

When processing background materials, we analysed internal guidelines, external and internal documents of the enterprises, project and programme documentation, software applications, accounts, questionnaires, available domestic and foreign publications and legislative acts related to the issues in question. 
When conducting analyses, we focused predominantly on information background of management processes, business information system concepts, integrity and functionalities of business information systems, accounting methods and systems, reliability of the accounting systems, stability of the systems in relation to management and demands of managers related to quality and accessibility of information. Business information systems of the selected enterprises were analysed from the perspective of providing data for managers, demands related to management and decision-making, functional and legislative reliability and possibilities for supporting the competitiveness achievement.

When collecting data, the following data collection methods were used: direct and indirect observation, structured interview, questionnaire, business documents analysis.

As for the methodology, the following basic research methods are applied: analysis, synthesis, comparison, graphical depiction and horizontal as well as vertical data analysis. Processing and evaluation of the research conducted among the selected agricultural enterprises was supported by large volume of statistical data. The selected agricultural enterprises comprised of limited liability companies, cooperatives, joint stock companies and also natural persons. The enterprises use both single entry and double entry accounting. Then, we focused on examination of the available economic software solutions by Slovak and Czech companies, with functionality applicable in all spheres of agricultural enterprises' activities. As many as 65 agricultural enterprises took part in the research. Size of enterprises by number of employees: $<10-15.91 \% ; 11-50-68.18 \%$ and $51-250-15.91 \%$. The enterprises are located in 6 counties. The most frequent group is represented by enterprises with $11-50$ employees - mediumsized companies $68.18 \%$.

The questionnaire consisted of 27 questions, with both open-ended and closed-ended questions. The Likert scale was also applied. The questionnaire was conceptualised on the basis of literature and some previous research. Some enterprises took direct part in the questionnaire design and cooperated in conducting the semi-structured interviews during querying.

The following indicators were devised for the questions focusing on the benefits and functions of information systems (Table 1).

\begin{tabular}{|l|l|}
\hline & Information system benefits \\
\hline B1 & $\begin{array}{l}\text { Significant reduction of time necessary to achieve } \\
\text { required data. }\end{array}$ \\
\hline B2 & $\begin{array}{l}\text { Information from various sources is available in one } \\
\text { spot. }\end{array}$ \\
\hline B3 & $\begin{array}{l}\text { Information from various sources is available } \\
\text { in a unified format. }\end{array}$ \\
\hline B4 & System enables to monitor the elementary indicators. \\
\hline B5 & $\begin{array}{l}\text { System enables to analyse and examine the reasons } \\
\text { behind emerging situations. }\end{array}$ \\
\hline & Information system functions \\
\hline F1 & Conducting financial analyses. \\
\hline F2 & Configuration of plans, budgets, calculations. \\
\hline F3 & Support for decision-making. \\
\hline F4 & Manufacturing management. \\
\hline F5 & Real-time stock management. \\
\hline F6 & Control of plans execution. \\
\hline F7 & Transportation management. \\
\hline F8 & Data of business partners. \\
\hline F9 & Remote access to data. \\
\hline
\end{tabular}

Source: own processing

Table 1: Research model indicators.

The data analysis was carried out with a help of a large statistical apparatus. Besides the basic descriptive statistics, correlations and extrapolation, we also used systemic methodology, aimed at searching connections among the individual issues in question. When designing models of satisfaction with information systems, we used multiple linear regressions and analysis of variance Anova. We examined the dependence of interval variable $\mathrm{Y}$ on several nominal variables (factors). The equation was devised on the basis of the general equation $\mathrm{Y}=\mathrm{b}_{\mathrm{o}}+\mathrm{b}_{1} \mathrm{x}$ and the acquired results.

\section{Results and discussion}

Information systems in enterprises are important from the perspective of strategic management and decision-making of top managers. They form a data base necessary for both internal and external users. A high-quality information system could provide real and updated information, thus becoming a useful instrument for managers, increasing efficiency of employees, ensuring and enhancing flexibility of an enterprise, fostering improved relations with customers and creating a strong tool for management of activities in an enterprise.

The decisions on business information systems are strategic and their consequences will become visible in a longer time horizon (Sirota et al., 2013). 
The addressed agricultural enterprises use automated information systems. All of the respondents claimed to have implemented a business information system. The most frequently implemented information systems are listed below (Graph 1).

The Aurus information system belongs to the most frequently used ones among agricultural enterprises (40.82\%). The most often implemented version is Ekopacket, providing complex services for its users. Aurus Ekopacket is the second generation of a complex, multi-user package of economic programmes designed for large, medium and small enterprises focused on trade, manufacturing or services, and also for budgetary and contributory organisations. The second most frequently used information system is Intes (18.37\% share). The information system is aimed at recording the use of fertilizers, seeds, chemical preparations and other components of the Good Farming Practice, and it is based on the use of traditional documents adjusted for use in electronic forms for control bodies. The third most frequently used information system in agricultural enterprises is SIDUS (10.20\% share). The SIDUS system is a product of a group of designers, analysts and programmers, contributing to the development and maintenance of the ASR ZpoK system (predecessor of SIDUS). Besides experience and traditions, the SIDUS system brings new approaches to information systems, it uses graphical environment to the maximal possible extent and efficient hardware with no limits and offers new options for users. Other software solutions are implemented by less than $10 \%$ of enterprises. Some $6.12 \%$ of them use the more universal and typical Pohoda software. The Pohoda software is often called economic software.
The Skeagis (2.04 \% share), geographical information system, providing information of the operational management of agriculture, enabling to process and use data of subjects located on the ground Skeagis offers three basic modules: Land register, Tenancy and Plot together with a GPS module. The system links written and graphical parts with the exact localisation of production spots in the field based on orthophotography.

It is very important for agricultural enterprises that their systems are connected with a land register, maps and agrarian portals, while being efficient in processing the agricultural agenda.

In the current rapidly changing society based on knowledge, information and ICT, it is not enough to implement an information system - users must be information-literate and information security must be ensured. Based on the research conducted in the selected agricultural enterprises, it could be stated that the number of employees has decreased recently and managerial functions are cumulated in enterprises. There was no independent department focused on administration and management of ICT established, in most of the examined enterprises. Absence of such a department significantly affects the emergence of a security incident. Although employees do have ICT at their disposal, they often have to make do with basic knowledge only; i.e. at lower levels of management, there is only a low level of knowledge of the given issue. This also affects behaviour of employees, which is often careless, regarding the information security (not enough attention is paid to basic data security, e.g. access passwords are either not defined or used by several employees). Currently, the quality of trainings and courses focused on increasing the information literacy of managers

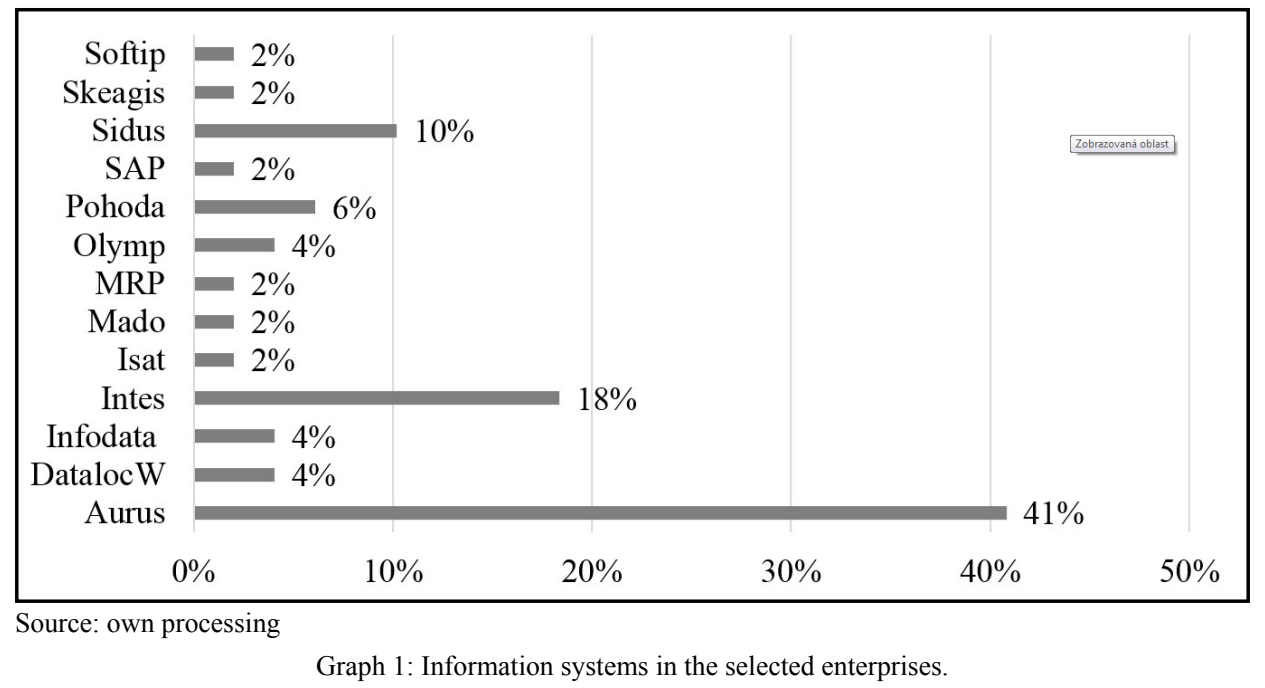


is at a very low level. Agricultural managers often underestimate the risks related to the information security and rely on basic protection provided by antivirus software. Simultaneously, the enterprises lack proper technological equipment (outdated technology), though at the same time it must be noted that software applications are being regularly updated. However, it is clear that small and medium-size agricultural enterprises lack internal directives focused on administration and management of information and communication technologies. The research results claim that the financial resources are the main reason behind the detected imperfections.

The most important benefit (scale: 0 for unsatisfied to 5 for the most satisfied) of business information systems according to the enterprises is B1 - significant reduction of time necessary to acquire the demanded data, $\mathrm{M}=4.30 \mathrm{pts}$, STDEV $=1.05 \mathrm{pts}$; followed by B2 - data from various sources available in one place, $\mathrm{M}=4.25 \mathrm{pts}, \mathrm{STDEV}=0.97 \mathrm{pts} ; \mathrm{B} 4-\mathrm{a}$ system enables users to monitor basic indicators, $\mathrm{M}=4.23$ pts, STDEV = 1.09 pts; B3 - information from various sources is available in a single format, $\mathrm{M}=3.93 \mathrm{pts}, \mathrm{STDEV}=1.02 \mathrm{pts}$; the least important benefit according to the enterprises is B5 - a system enables analysis and determining causes of the emerging situations, $\mathrm{M}=3.45 \mathrm{pts}$, $\mathrm{STDEV}=1.32$ pts.

Then, the significance of business information systems' functions was examined. The enterprises implied the following ranking of the significance: F1 - preparation of financial analyses, $\mathrm{M}=4.16$ pts, STDEV $=1,10$ pts; F2 - preparation of plans, budgets and calculations, $\mathrm{M}=4.11 \mathrm{pts}$, STDEV $=1.13$ pts; F5 - real-time stockholding, $\mathrm{M}=3.80$ pts, STDEV = 1.17 pts; F8 - data of business partners, $\mathrm{M}=3.61 \mathrm{pts}, \mathrm{STDEV}=1.38 \mathrm{pts}$;
F3 - support for decision-making, $\mathrm{M}=3.52 \mathrm{pts,}$ $\mathrm{STDEV}=1.21 \mathrm{pts} ; \mathrm{F} 9$ - remote access to data, $\mathrm{M}=3.48$ pts, STDEV = 1.69 pts; F4 - Production management, $\mathrm{M}=3.39 \mathrm{pts}, \mathrm{STDEV}=1.56 \mathrm{pts}$; F6 - control of the plan implementation, $\mathrm{M}=3.09$ pts, STDEV $=1.60 \mathrm{pts}$; the least important function of a business information system according to the respondents is F7 - Transportation management, $\mathrm{M}=1.93$ pts, $\mathrm{STDEV}=1.63 \mathrm{pts}$.

The overall satisfaction with meeting the requirements on the current business information systems related to decision-making and management is at the level of $\mathrm{M}=3.91 \mathrm{pts}$, $\mathrm{STDEV}=0.94 \mathrm{pts}$. The level of satisfaction is considered adequate.

The levels of satisfaction with the implemented business information systems directly affect the need to change systems or to purchase further modules. Purchase of the further modules is affected by increasing computerisation, limitations of the current systems and also external factors. The total of $14 \%$ of enterprises plan replacing the current information systems with the complex ones; $5 \%$ of enterprises plan purchasing further modules to the implemented business information systems.

After the analysis of satisfaction with the implemented information systems, the benefits affecting the rate of satisfaction were examined.

Satisfaction with business information systems is predetermined by all benefits of information systems at the significance level of $\mathrm{p}=0.05$. The model is statistically significant, as the value $\mathrm{p}<0.000$. However, not all benefits in the model are significant at the significance level of $p=0.05$. Hence, it is necessary to eliminate and reduce several benefits and create the following model

\begin{tabular}{|c|c|c|c|c|c|c|}
\hline \multicolumn{4}{|c|}{ Model $1 A$} & \multicolumn{3}{|c|}{ Modify Model $1 A$} \\
\hline Explanatory variable & $B$ & $S E B$ & $\beta$ & $B$ & $S E B$ & $\beta$ \\
\hline B1 & 0.013 & 0.213 & 0.014 & \multirow{4}{*}{0.456} & \multirow{4}{*}{0.125} & \multirow{4}{*}{$0.472 * *$} \\
\hline B2 & 0.392 & 0.244 & 0.405 & & & \\
\hline B3 & 0.212 & 0.145 & 0.231 & & & \\
\hline B4 & -0.068 & 0.210 & -0.074 & & & \\
\hline B5 & 0.173 & 0.106 & 0.244 & 0.211 & 0.092 & $0.027^{*}$ \\
\hline Adjusted $\mathrm{R}^{2}$ & & 0.384 & & \multicolumn{3}{|c|}{0.395} \\
\hline $\mathrm{F}(5,38)$ & & $6.352 * *$ & & \multicolumn{2}{|c|}{$\mathrm{F}(2,41)$} & \multirow[t]{2}{*}{$15.050 * *$} \\
\hline $\mathrm{N}$ & & & & & & \\
\hline
\end{tabular}

Note: $* \mathrm{p}<.05, * * \mathrm{p}<.01$

Source: own processing

Table 2: Model of the rate of satisfaction with the implemented business information systems in relation to the proclaimed benefits. 
(Modify 1A).

The model determining the satisfaction of the enterprises with their business information systems is statistically significant $p<0.000$ at the significance level of $p=0.05$. Up to 39.50 $\%$ of points for satisfaction is attributed to the B2 and B5 benefits - data from various sources available in one place and a system enables analysis and determining causes of the emerging situations, respectively. Based on the above, the following formula could be drawn up:

$$
\mathrm{S}=1.242+0.456 * \mathrm{~B} 2+0.211 * \mathrm{~B} 5
$$

If the benefit $\mathrm{B} 2$ rate increases by 1 point, the satisfaction with a business information system increases by $0.46 \mathrm{pts}$. If the benefit B5 rate increases by 1 point, the satisfaction with a business information system increases by 0.21 pts. If $\mathrm{B} 2$ and $\mathrm{B} 5$ are equal to zero, the satisfaction with a business information system is 1.242 pts.

The satisfaction with the implemented business information systems are affected both by benefits and their functions.

Satisfaction with business information systems is predetermined by all functions of business information systems at the significance level of $p=0.05$. The model is statistically significant as the value $p=0.019$. However, not all benefits in the model are significant at the significance level of $p=0.05$. Hence, it is necessary to eliminate and reduce individual benefits and create the following model (Modify 1B).
The model predetermining the satisfaction of the enterprises with the implemented business information systems is statistically significant $\mathrm{p}<0.000$ at the significance level of $\mathrm{p}=0.05$. Up to $28.90 \%$ of points related to the satisfaction are explained by the information system functions F2 and F8, preparation of plans, budgets and calculations and data of business partners, respectively. Based on the above, the following formula could be drawn up:

$$
\mathrm{S}=1.542+0.372 * \mathrm{~F} 2+0.232 * \mathrm{~F} 8
$$

If the function F2 rate increases by 1 point, the satisfaction with a business information system increases by $0.37 \mathrm{pts}$ on the average. If the function F8 rate increases by 1 point, the satisfaction with a business information system increases by 0.23 pts. If $\mathrm{F} 2$ and F8 are equal to zero, the satisfaction with a business information system is 1.542 pts.

Agricultural managers evaluate the implemented information systems according to their functions. There are several reasons leading to implementation of information systems and automation of processes. They could be derived from benefits of the implemented information systems. Significant reduction of time necessary to reach the required data, available in one place is the most important benefit of information systems. Systems enable monitoring the basic indicators and information from various resources is at disposal in one place and in a single format. Satisfaction with the implemented systems is determined by their functions. According

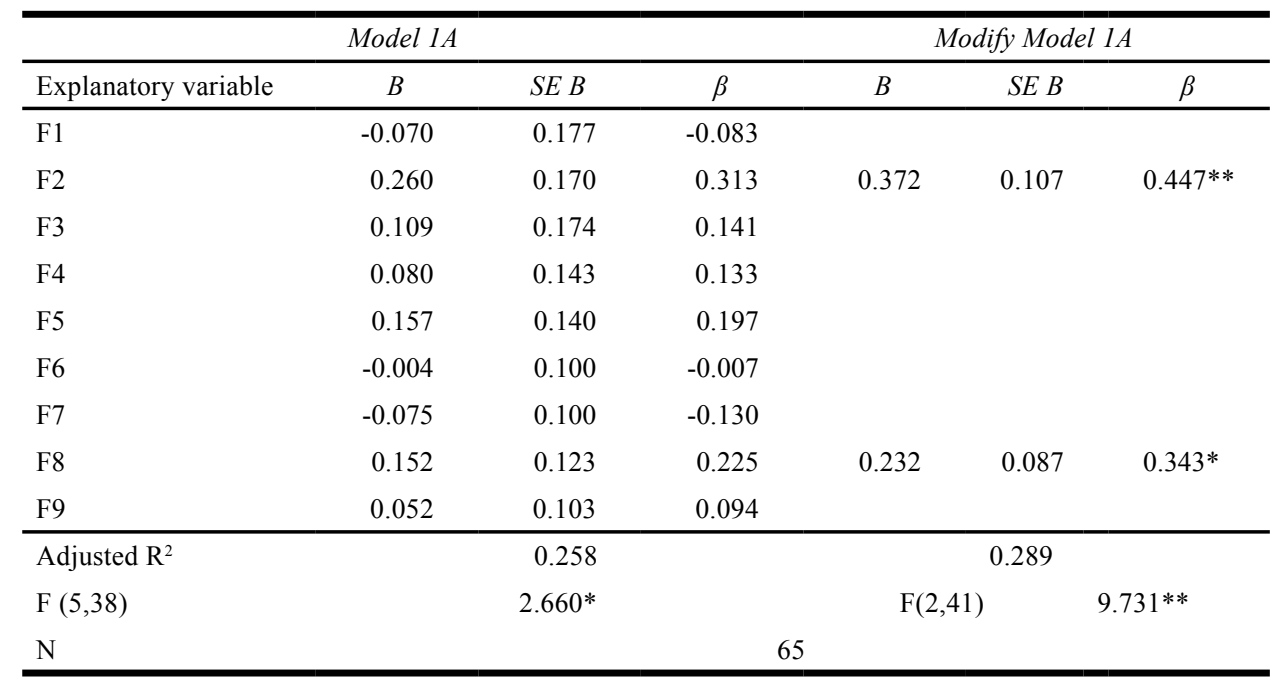

Note: $* \mathrm{p}<.05, * * \mathrm{p}<.01$

Source: own processing

Table 3: Model of the rate of satisfaction with the implemented business information systems predetermined by their functions. 
to the agricultural managers, ability to prepare financial analyses, plans, budgets and calculations, stock management in a real time basis, data on business partners, support for decisionmaking, remote access to data, manufacturing management and plan implementation control are the most important functions of business information systems. The overall satisfaction of managers with the business information systems reached $\mathrm{M}=3.91 \mathrm{pts}, \mathrm{STDEV}=0.94 \mathrm{pts}$ (scale: 0 for unsatisfied to 5 for the most satisfied). This level of satisfaction with the implemented business information systems is considered satisfactory. It could be summarised that it is very important for an implemented business information system to meet all needs of managers. The rate of satisfaction with the implemented business information systems directly affects the need to change information systems or to purchase modules. The purchase of new modules is limited by computerisation, limits of the currently implemented systems and also by external factors. However, $14 \%$ of the enterprises plan to replace their systems with the complex ones and $5 \%$ of enterprises plan to purchase further modules to their already implemented business information systems.

Complex business information systems used by agricultural enterprises cover several areas: accounting $97.73 \%$, stock management $86.36 \%$, human resources and payrolls $86.36 \%$, non-current assets $90.91 \%$. The modules are integrated into a single business information system providing complex processing, analyses and output reports. The selected enterprises use business information system predominantly to carry out accounting, address non-current assets, stock management and finally also human resources and payrolls. Accounting data represent essential background source facilitating decision-making. It is important that they are complete, trustworthy, early and complex. Within the research, managers of the agricultural enterprises claimed that they identified mistaken decisions due to incomplete, untrue or belated information up to 5 times in $65.91 \%$ of cases, often in $11.36 \%$ of cases and $22.73 \%$ of managers had not experienced such a mistake throughout their practice.

High-quality planning is more than important for successful management, as it helps in estimating opportunities and risks and also enables the permanent control of reaching the set goals. Information systems are able to contribute to improved management functions and they are also suitable instruments for automation of processes.
An enterprise could devise its own manufacturing, financial and time plan of plant production. Each farmer must record his/her activities regarding the agricultural land and document adhering to relevant legislation.

Based on the above information, it is necessary that the managers reconsider their information systems and modify them according to the needs of enterprises and conditions of markets. However, it is necessary to realise that modifications shall not remove imperfections only but after modifications, systems shall enable enterprises to achieve longterm prosperity and competitiveness at domestic and also foreign markets.

In the proposed paper, we have presented the results that we have gained in examining agricultural enterprises' information systems in the Slovak Republic. Agricultural enterprises in the Slovak Republic prefer information systems that allow recording, processing and evaluation of data from in-house accounting with a focus on plant and animal production. Based on the survey and the analysis, which is part of the research project named Modeling of Harmonization Solutions for Financial and Tax Accounting at Agricultural Business Organisations (coordinated by Aleksandras Stulginskis University, Lithuania), we have identified a requirement to improve and streamline monitoring of accounting information in the agricultural information systems. The most common problems include: the linking of economic modules to the plant and animal production monitoring systems, the incompatibility of individual software that makes it difficult to provide data for business management and data collection for government institutions.

Based on the processing of the data obtained from the survey, we have identified certain deficiencies in the area of data processing and provision. We propose to innovate these agricultural enterprise information systems, namely:

- Improve the module for the plant and animal production recording by supplementing the system of creation and monitoring of calculations,

- Automate the data provision for the external environment, such as data on agricultural production for the purpose of institution monitoring at the national level as well as at the level of European Union institutions,

- expand enterprise information systems to track and manage customer relationships (CRM), 
- add a module for monitoring the quality of plant and animal production,

- provide information support for ecological management,

- improve communication with external business partners and the availability of information from foreign markets,

- respond more quickly to the development of information technologies and their implementation in the agricultural environment. Currently, the availability of data is addressed via cloud computing.

At present, besides the above mentioned issues, we are also involved in integrating the functionality of data recording and evaluating from the enterprise information systems in agricultural enterprises within the in-house environment, which will be the underlying asset for decision-making. Our findings of the current state and suggestions can be beneficial to countries that have not implemented similar information systems in their enterprises (see our paper), respectively their level of informatisation is lower.

\section{Conclusion}

Agricultural enterprises come across the growing trend of computerisation in all spheres of plant production, animal production and management. ICTs digitalise the following processes: seed selection, soil preparation, sowing, harvesting, processing, storage and distribution. They are incorporated into management and are inevitable for acquiring, processing and storing data. Modern technological tools, machines, devices and mechanisms are directly operated by software applications and systems. Virtualisation of the processes through cloud computing establishes a single modern and complex system of agricultural smart enterprises supported by ICTs.

Efficient business software becomes inevitable for agricultural enterprises. Such software must possess high-quality intranet and Internet structures. Implementation of such a model requires suitable technological background as well as methodological and organisational conditions within an enterprise.

Currently, enterprises react to the need to modify their business information systems in three ways: purchase of new software, development of new software, or improvement of the existing software (already implemented in an enterprise). It is crucial that implementation of an information system leaves a satisfied user and fulfilled (more or less) strategic goals of an organisation, or goals related to all levels of management and all areas using IS/IT.

The demands of managers on information systems were also identified. Flexibility and integration are the basic factors of well-functioning economic systems. It is necessary that systems react swiftly on changes not only in ordinary situations, but also in the strategic activities related to products and markets. Systems shall lead to optimisation of operational and economic processes and be able to warn users in cases of undesired developments.

The level of computerisation in the examined enterprises is given by their location, access to the Internet, digital literacy of their employees and used technologies. However, it is clear that the use of new information and communication technologies and information systems could make agricultural enterprises more efficient, strengthen their competitive positions and equip them with strategic competitive advantages.

\section{Acknowledgements}

Supported by the Scientific Grant Agency of the Ministry of Education of Slovak Republic and the Slovak Academy of Sciences VEGA $1 / 0489 / 15$ "Increasing the efficiency of decisionmaking of managers with the support of information systems and accounting”.

Corresponding authors:

Ing. Vladimír Bolek, PhD.

Department of Information Management, Faculty of Business Management

University of Economics in Bratislava, Dolnozemská cesta 1, 85235 Bratislava, Slovak Republic

ORCID: https://orcid.org/0000-0003-1144-278X

Phone: +421/2/6729 5622,E-mail: vladimir.bolek@euba.sk 


\section{References}

[1] Armbrust, M., Fox, A., Griffith, R., Joseph, AD., Katz, R., Konwinski, A., Lee, G., Patterson, D., Rabkin, A., Stoica, I. and Zaharia, M. (2010) "A view of cloud computing”, Communications of the ACM, Vol. 53, No. 4, pp. 50-58. DOI 10.1145/1721654.1721672.

[2] Basl J. and Blažíček R. (2008) "Podnikové informační systémy” (in Czech), Grada Publishing, Prague. ISBN 978-80-247-4307-3.

[3] Forestier, E., Grace, J. and Kenny, C. (2002) "Can Information and Communication Technologies Be Pro-Poor?", Telecommunications Policy, Vol. 26, No. 11, pp. 623-646. ISSN 0308-5961. DOI 10.1016/S0308-5961(02)00061-7.

[4] Gartner, Inc. (2016) "BI Intelligence Estimates”. (Study, conference material)

[5] Goyal, A. (2010) "Information, Direct Access to Farmers, and Rural Market Performance in Central India”, American Economic Journal-Applied Economics, Vol. 2, No. 3, pp. 22-45. ISSN 1945-7782. DOI 10.1257/app.2.3.22

[6] Hamranová, A. (2013) "Aspekty implementácie Business Intelligence v slovenských podnikoch" (in Slovak), Ekonóm, ISBN 978-80-225-3603-5.

[7] Havlíček, Z., Lohr, V., and Benda, P. (2009) "ICT and agritourism in Czech Republic", APSTRACT: Applied Studies in Agribusiness and Commerce, 3, [Online]. Available: http://ageconsearch.umn. edu/bitstream/53541/2/10_ICT_Apstract.pdf [Accessed: 20 Jan. 2018].

[8] Jensen, R. (2007) "The Digital Provide: Information (Technology), Market Performance, and Welfare in the South Indian Fisheries Sector", Quarterly Journal of Economics, Vol. 122, No. 3, pp. 879-924. E-ISSN 1531-4650, ISSN 0033-5533. DOI 10.1162/qjec.122.3.879.

[9] Kokles, M. and Romanová, A. (2007) “Informačný systém podniku” (in Slovak), Ekonóm, Bratislava. ISBN 978-80-225-2286-1.

[10] Kuncova, M., Hedija, V. and Fiala, R. (2016) “A Comparison of Specialised Agricultural Companies Performance", International Scientific Conference on Quantitative Methods in Economics - Multiple Criteria Decision Making XVIII. ISBN 978-80-972328-0-1.

[11] Lio, M. and Liu M.-Ch. (2006) "ICT and Agricultural Productivity: Evidence from Crosscountry Data", Agricultural Economics, Vol. 34, No. 3, pp. 221-28. E-ISSN 1574-0862. DOI 10.1111/j.1574-0864.2006.00120.x.

[12] Maumbe, B. M. and Okello, J. (2010) "Uses of Information and Communication Technology (ICT) in Agriculture and Rural Development in Sub-Saharan Africa: Experiences from South Africa and Kenya", International Journal of ICT Research and Development in Africa (IJICTRDA), Vol. 1, No. 1, pp. 1-22.

[13] Novotný, O., Pour, J. and Slanský, D. (2005) "Business Intelligence” (in Czech), Grada Publishing, Prague. ISBN 80-247-1094-3.

[14] Röller, L.-H. and Waverman, L. (2001) "Telecommunications Infrastructure and Economic Development: A Simultaneous Approach”, The American Economic Review, Vol. 91, No. 4, pp. 909-923. ISSN 0002-8282. DOI 10.1257/aer.91.4.909.

[15] Scheps, S. (2008) "Business Intelligence for dummies", John Wiley and Sons Ltd, Chichester. ISBN 978-1-118-05141-2.

[16] Sirota, M., Juanchich, M., Kostopoulou, O. and Hanak, R. (2013) "Decisive Evidence on a SmallerThan-YouThink Phenomenon: Revisiting the "1-in-X" Effect on Subjective Medical Probabilities", Medical Decision Making, Vol. 34, No. 4, pp. 419-429, E-ISSN 1552-681X, ISSN 0272-989X. DOI 10.1177/0272989X13514776.

[17] Stuchly, P. and Krutakova, P. (2015) “Analysis of a process in relation to the enterprise information system", ICABR 2015. $1^{\text {st }}$ ed. Mendel University, Brno. [Online]. Available at: http://www.icabr. com/fullpapers/icabr2015.pdf. [Accessed: 10 Jan. 2018]. 
[18] Tóth, Z. (2012) "The current role of accounting information systems", Theory, Methodology, Practice. Vol. 8, No. 1, pp. 91-95. [Online]. Available: http://phd.lib.uni-miskolc.hu/JaDoX_Portlets/ documents/document_13628_section_5784.pdf [Accessed: 20 Jan. 2018].

[19] Tyrychtr, J., Ulman, M. and Vostrovský, V. (2015) "Evaluation of the state of the business intelligence among small czech farms", Agricultural Economics, Vol. 61, No. 2, pp. 63-71. E-ISSN 1805-9295, ISSN 0139-570X. DOI 10.17221/108/2014-AGRICECON.

[20] Waverman, L., Meschi, M. and Fuss, M. (2005) “The Impact of Telecoms on Economic Growth in Developing Countries", Vodaphone Policy Paper Series 2, pp. 10-24. [Online]. Available at: http://www.vodafone.com/content/dam/vodafone/about/public_policy/policy_papers/_ public_ policy_series_2.pdf [Accessed 25 Jan. 2018].

[21] Williams S. and Williams N. (2007) “The profit impact of Business Intelligence”, Morgan Kaufmann Publishers, San Francisco. ISBN 978-0123724991. 